\title{
A CANADIAN EXCEPTION TO THE Punitive Turn? Community Responses to Policing Practices in Winnipeg's INNER CITY ${ }^{1}$
}

\author{
Elizabeth CoMack \\ JIM SILVER
}

\begin{abstract}
While criminologists have made the case that a "punitive turn," spurred on by penal populism, is being witnessed in several Western countries, some have argued that Canada is the exception to this trend. But recent developments in Winnipeg, Manitoba suggest that a made-in-America crime control strategyzero-tolerance policing - has been imported into the Winnipeg context to combat the pressing problems of drugs, gangs, and violence in inner-city communities. Can this development be interpreted as evidence of a punitive turn? Has penal populism found its way into a Canadian jurisdiction? Drawing on interviews with inner-city residents, businesspeople, and community workers, we show that people in Winnipeg's inner city have a sophisticated understanding of the causes of social problems in their neighbourhoods and a very clear vision of what they believe the role of police in the inner city should be: one in which the police work with the community as part of a wider effort of community mobilization. These findings do not support the view that Winnipeg is a Canadian exception to the punitive turn. Rather, they suggest the presence of community resistance to aggressive "get tough" strategies of crime control, and of the potential to fashion radically different solutions to the complex problems confronting inner-city communities.
\end{abstract}

Résumé. Bien que les criminologues aient établi le bien-fondé qu'un «virage punitif», incité par un populisme pénal, se manifeste dans plusieurs pays occi-

1. The research on which this paper is based was made possible by a grant from the Law for the Future Fund, an initiative of the Law Commission of Canada and the Canadian Bar Association. The authors are indebted to Jessica Antony, Cassandra Costa, Florence Gray, Claudette Michel, Gosia Parada, and Sue Thiebaut for their hard work on the project, and to the community respondents who took the time to provide us with thoughtful answers to our questions. We are also appreciative of the work of Kevin Haggerty and the three CJS reviewers for providing us with insightful feedback on an earlier version of this paper. 
dentaux, certains prétendent que le Canada fait exception à cette tendance. Or, les récents développements à Winnipeg, au Manitoba, portent à croire qu'une stratégie américaine de lutte contre le crime, c'est-à-dire un maintien de l'ordre avec tolérance zéro, a été importée à Winnipeg pour régler les problèmes pressants de drogues, de gangs de rue et de violence dans les communautés des quartiers centraux de la ville. Ce développement peut-il être interprété comme preuve d'un virage punitif? Le populisme pénal est-il entré dans la juridiction canadienne? À partir d'entrevues avec des résidents, des gens d'affaires et des travailleurs des communautés des quartiers centraux, nous démontrons que les habitants de ces quartiers de Winnipeg comprennent bien les causes des problèmes sociaux qui y existent et qu'ils ont une vision très claire de ce que le rôle de la police devrait être dans ces quartiers, à savoir que la police devrait travailler avec la communauté dans le cadre d'une mobilisation communautaire plus large. Ces conclusions ne prouvent pas que Winnipeg soit l'exception canadienne au virage punitif. Au contraire, elles suggèrent la présence d'une résistance communautaire aux stratégies disciplinaires agressives de lutte contre le crime et la possibilité d'arriver à des solutions tout à fait différentes aux problèmes complexes auxquels les communautés des quartiers centraux des villes font face.

W ithin the criminological literature, increasing attention has been fixed on the "punitive turn." Governments, backed by populist demand, are resorting more and more to criminal justice policies and practices aimed at "getting tough on criminals." Mass incarceration, mandatory sentences and three-strikes laws, the use of the death penalty, supermax prisons, indefinite detention, sex offender registries and community notification laws, boot camps, prison chain gangs, and zerotolerance policing strategies are typically included in the list of such punitive policies and practices (Pratt et al. 2005; Sudbury 2005; Pratt 2000; Garland 2001; Wacquant 2000; 2001; 2006; Simon 1997; 1999). The extent to which this "new punitiveness" has taken hold has been the subject of much discussion and debate. Jeffrey Meyer and Pat O'Malley (2005:202), for instance, suggest that "the accuracy of accounts of a new punitive age may be geographically bounded."

Some writers have argued that Canada is an exception to trends identified in other countries, especially the United States. According to Meyer and O'Malley (2005), Canada has not followed the path of its neighbour to the south. Citing the availability of therapeutic programming in federal prisons, the relative stability of incarceration rates, the lack of public support for "get tough" policies, and the disavowal of an American-style response to crime, they maintain that Canadian criminal justice "cannot be subsumed under a general model of a global punitive turn" (Meyer and O’Malley 2005:213). Similarly, John Pratt (2007) argues that Canada has resisted the rise of a penal populism that advo- 
cates for more punitive, "get tough" crime control strategies. According to Pratt (2007:153):

There seems to be widespread consensus in Canadian political and bureaucratic circles that the United States' crime control options have been a disaster and should not be repeated in Canada. This has meant that, in relation to penal policy, populist strategies have been able to make little headway there. While the simplistic and guileful slogans - three strikes, zero tolerance and so on - which emanate from penal development in the United States have been flashed around the world, Canada has had the benefit of more old fashioned neighbourly communication with that country and sees its realities very clearly. As a result it prefers a 'Canadian way' of dealing with social problems, in much the same way that it wants other aspects of Canadian life to reflect the identity of that country rather than the United States.

Such broad claims about Canadian criminal justice policies and practices are problematic. Criminal justice interventions - from policing to courts to prisons - are complex, and can differ from region to region and city to city. As Pratt and his colleagues (2005:xvi) have acknowledged, there is often considerable variation not only between countries, but also within them, as "trends evident at a national level often mask quite striking intra-national differences."

Casting criminal justice policies and practices as a "punitive/nonpunitive" dichotomy ignores the diversity, contradictions, and tensions that often characterize such initiatives (Matthews 2005:195). Policing is a case in point. Just as punishment can be "volatile and contradictory" (O’Malley 1999), police service delivery can be a multifaceted endeavour involving strategies or rationales from the traditional incident-based model of policing, to community policing, to zero-tolerance policing. In addition, while police departments may borrow strategies that become popular in other jurisdictions, whether or not they take hold will depend upon the particular nature of the social problems that prevail in the communities in which they are implemented and the receptiveness of the citizenry to these initiatives.

Similarly, resting claims of a "punitive turn" on populist sentiments that call for "get tough" approaches to crime suggests that populism is, by definition, a backward or reactionary form of political mobilization. Such a reading disregards the ways in which public demands can be filtered, shaped, and moderated before they are translated into criminal justice policy (Matthews 2005:188-189) - not to mention the ways in which criminal justice policy and practice can likewise be thwarted or resisted by a mobilized public. 
Clearly, claims of a "punitive turn" - and the Canadian exception - could benefit from closer empirical investigation of the ways in which criminal justice policies and practices emerge and play out in particular local contexts. The city of Winnipeg, Manitoba offers one such opportunity. Contrary to Pratt's (2007) assertion that Canada has eschewed American-style crime control strategies and simplistic slogans such as "zero tolerance" in favour of a "Canadian way," recent developments in Winnipeg suggest that a made-in-America crime control strategy zero-tolerance policing - has been imported into the Winnipeg context, ostensibly with the backing of popular support, in order to combat what is understood to be a pressing problem of gangs, drugs, and violence in inner-city communities. Can this development be interpreted as evidence of a "punitive turn"? Has penal populism found its way into at least one Canadian jurisdiction?

At first glance, the move to implement zero-tolerance policing in Winnipeg aligns with the wider "punitive turn." However, our aim is to provide a different reading. Drawing on interviews with inner-city residents, businesspeople, and community workers, we show that the Winnipeg experience is more complicated than it initially appears. While zero-tolerance policing has been enthusiastically promoted by local politicians (the mayor of the city, in particular), there does not appear to be community-based support for the strategy, at least when "community" is defined as those citizens who are most affected by it: residents of the inner city and those who work closely with them.

Interviews conducted with people in the inner city reveal that while they are deeply concerned about safety and security issues - especially the prevalence of drugs, gangs, and violence in their neighbourhoods they have a sophisticated understanding of the underlying causes of these issues. Respondents are also critical of the role played by police in their community, especially in relation to aggressive policing strategies. The residents we interviewed have a very clear vision of what they believe the role of police in the inner city should be: one in which the police are part of a wider effort of community mobilization and work with the community in implementing community-driven solutions to crime. Rather than providing evidence of a "penal populism," these findings suggest a more progressive understanding of crime and crime control strategies, with the potential not only for community resistance to aggressive "get tough" strategies of crime control but also for radically different solutions to the complex problems confronting inner-city communities. 


\section{WinNIPEG's INNER-CITY COMMUNITIES}

Over the last decade, concerns about crime and disorder have heightened in Winnipeg. Newspaper headlines have been warning about the "Mean Streets of Manitoba" (Winnipeg Free Press, 23 July 1998:A1) and the "hardscrabble streets of Winnipeg" (Winnipeg Free Press, 19 December 2007) for many years, and local politicians have increasingly framed their election strategies around the need to "fight crime." Despite its moderate size relative to other Canadian cities, Winnipeg has garnered a reputation as a major site of crime and violence. In 2004, the city ranked first among the nine major metropolitan centres for homicides, robberies, and motor vehicle thefts, and second for break-ins (Statistics Canada 2005). Much of this activity has been concentrated in Winnipeg's inner-city communities. A 2004 study done by the Canadian Centre for Justice Statistics found that the closer one goes to the geographic core of Winnipeg, the higher is the incidence of crime. Authors Robin Fitzgerald, Michael Wisener, and Josée Savoie (2004:8) concluded that "After taking into account all other factors, the level of socio-economic disadvantage of the residential population in a neighbourhood was most strongly associated with the highest neighbourhood rates of both violent and property crimes." Other studies (see, for example, Lezubski et al. 2000; Kazemipur and Halli 2000) have shown that rates of poverty, unemployment, and limited labour force participation - i.e., "socio-economic disadvantage" - are considerably worse in the inner city than in Winnipeg as a whole. Crime and violence, therefore, correlate strongly with poverty and related conditions, and both are more prevalent in Winnipeg's innercity neighbourhoods.

Winnipeg's inner-city communities are also racialized spaces. In the 1960 s, Aboriginal peoples began to move from rural and reserve communities to urban centres, their numbers increasing significantly in the 1970s and 1980s. Many arrived in Winnipeg ill-prepared for urban industrial life, a result in large part of the residential school system, which did far more harm than good, leaving many Aboriginal people without adequate formal educational qualifications (Knockwood 2001; Milloy 1999). They concentrated in Winnipeg's inner city, at first because housing there was least expensive, and in subsequent decades because that was where other Aboriginal people already lived. But they were moving into neighbourhoods in which jobs - particularly the kinds of industrial jobs that historically have been available to those with limited formal educational qualifications - had disappeared. With few well-paid jobs available, and facing systemic racism and discrimination because they were "different," many Aboriginal people were effectively locked out 
of the formal labour market. In very recent years, growing numbers of immigrants and refugees from war-torn countries have been arriving in Winnipeg, many with low levels of formal education as a result of poverty and war. Most are locating in the inner city, for the same reasons that low-income people have for decades located there (Kazemipur and Halli 2000).

The result of these various processes has been the concentration in Winnipeg's inner city of poverty and, to a considerable extent, racialized poverty. Meaningful, well-paid jobs are scarce. Housing is frequently inadequate (Deane 2006; Silver 2006a). Very large numbers of innercity people have been "raised poor," and have never known anything but poverty and joblessness. For many, a culture of despair has emerged - a culture beyond the experience and thus, often, the understanding of more well-to-do Canadians.

It is not surprising that crime flourishes in this context. This is particularly so when street drugs are readily available as a means of escape, and can be bought and sold at prices and in volumes sufficient to earn a living well beyond what can be earned in part-time, low-wage, nonunion, service sector "McJobs" (Ritzer 2004). The illegal trade in drugs has become more insidious over the last decade, with drugs such as crack cocaine and crystal methamphetamine being distributed on the street and via "crack houses" in inner-city neighbourhoods. For many young and disproportionately Aboriginal - women, employment in the street sex trade is often their only recourse for getting by (Seshia 2005; Brown et al. 2006). Street gangs are also an issue of concern. In the mid 1990s, Winnipeg gained the reputation as the "gang capital of Canada," and names such as Indian Posse, Manitoba Warriors, and Deuce became part of the public discourse. While law enforcement officials have been quick to locate these gangs within the parlance of criminal organizations (McLeod 2004), Aboriginal leaders and researchers have been adamant in situating gangs as a contemporary manifestation of, and response to, colonization (Fontaine 2006; Deane et al. 2007).

Increasingly, therefore, concerns about the prevalence of drugs, gangs, and violence in inner-city communities have figured prominently in Winnipeg. The Winnipeg Police Service (WPS) is one of the organizations assigned the job of responding to these concerns.

\section{Policing Strategies}

As in other jurisdictions, police service delivery in Winnipeg has reflected a range of models adopted over time, in large part depending 
upon fiscal resources and the direction initiated by municipal leaders and/or police management. Three models in particular are evidenced in the Winnipeg experience: the traditional model of policing, community policing, and, most recently, zero-tolerance policing.

The traditional model of policing, with its roots in the early 20th century, emphasizes a military style of organization with a focus on centralization and bureaucratization (hierarchies and chains of command), standardization (of recruitment, training, and patrol methods), reliance on technology (radio-equipped patrol cars and computerized dispatch systems), and specialization (youth units, morals units, homicide units, and the like). Envisioning police as "crime fighters," this model is a reactive, incident-driven one whereby police work involves patrolling neighbourhoods in cars, responding to calls from the dispatcher sending them to a crime scene. The focus is on serious forms of crime as opposed to maintenance of community social order or general service delivery, and success is measured by arrest statistics (especially for violent and property crimes) (Morash and Ford 2002; Herbert 2001; Greene 2000). This reactive, incident-driven form of policing has predominated in Winnipeg historically, and currently constitutes the core of Winnipeg's innercity policing strategy. ${ }^{2}$

By the 1980s, however, a variety of commentators began to argue that the traditional model was ineffective (Wilson 1975; Kelling 1974; Sherman 1974). The increasing scepticism about the traditional model's ability to "fight crime," coupled with a recognition that police on their own cannot solve crime and that communities also share in the responsibility for addressing crime problems, led to a community policing movement in Canada, the United States, and the United Kingdom. Described more as a philosophy than a specific program (Clairmont 1991:471), community policing involves a multiagency approach to service delivery, a generalist police role, and a greater community involvement at the local level (Linden et al. 2000; Brodeur 1998; Murphy 1993; Hamilton and Sinclair 1991). Rather than "fighting crime," the emphasis is on crime prevention and community building. Rather than arrest statistics, success is measured in terms of greater community satisfaction with the police, an increased sense of safety and security (reduction in fear of crime) in the neighbourhood, and a greater sense of ownership and partnership on the part of community groups and police in solving an area's problems (Clairmont 1991).

By the mid 1990s, researcher Barry Leighton (1994:209) was able to claim that "community policing is firmly established as the dominant

2. Interview with (then) Winnipeg Police Service Chief Jack Ewatski, September 5, 2006. 
orientation or philosophy" in Canada and that "the overwhelming public rhetoric of Canadian police chiefs indicates they are committed to the paradigm shift, in principle and philosophy." Generally speaking, the success of these initiatives has depended upon the police leadership to promote a community-policing philosophy and usher in changes in their respective departments. This was certainly the case in Winnipeg when David Cassels took on the position of Chief of the Winnipeg Police Service in May of 1996. Cassels began implementing a community policing model that included the assignment of 20 foot patrol officers in inner-city neighbourhoods. As reflected on its official website (http://Winnipeg.ca/ police), the WPS continues to maintain a commitment to community policing. One form of this commitment is a School Resource Officer Program, which places uniformed police officers in inner-city schools. Designed as a preventive strategy with a long-term focus, School Resource Officers become a regular presence in the schools to develop positive relationships and a sense of trust with students and staff.

Despite the professed commitment to a community policing philosophy, there are concerns about the extent to which community policing initiatives have affected the hierarchical structure and bureaucratic organization of police services. François Dumaine and Rick Linden (2005), for instance, have noted that initiatives such as community police centres have been poorly integrated into the core functions of their departments, and Jack Greene (2000:332) has likened efforts to change internal police routines to "bending granite." Commentators have also noted that individual police officers have resisted efforts to implement community policing, as this model runs counter to a police culture premised on the exercise of force and a pronounced sense of morality ("getting the bad guys"). As Steve Herbert (2001) notes, these components of police culture are at odds with community policing. So although community policing garnered considerable attention and support in the mid-1980s, the 1990s saw the advent of yet another model: zero-tolerance policing.

Zero-tolerance policing is similar to community policing in that it involves an increased police presence or visibility in the community and a more decentralized authority structure. However, it differs from the community policing model in significant ways. For one, the main goal of zero-tolerance policing is to maintain order in a "hyper-aggressive" manner (Greene 1999:175). Panhandlers, street sex trade workers, streetlevel drug users, the homeless, and the disorderly are the main targets of this approach. To this extent, zero-tolerance policing shares the focus on law enforcement found in the traditional model. Like the traditional model, it also relies upon a more aggressive, militaristic style of policing and typically involves giving police officers increased powers to stop 
and search citizens for minor law violations. Zero-tolerance policing eclipses the active role of the citizenry with the more aggressive powers exercised by the police (for example, practices of intimidation and arrest), instead of the community policing concept of citizens and police as "co-equal partners in the construction and evaluation of tactics aimed at ameliorating community distress" (Herbert 2001:446). With the zerotolerance approach police measure "success" by counting field stops and the types of behaviour occurring in targeted locations (Greene 2000).

William Bratton championed zero-tolerance policing while serving as the Police Commissioner of New York City in the mid 1990s. ${ }^{3}$ Bratton was appointed by Mayor Rudolph Giuliani, elected to office in 1993 after a campaign strongly focused on issues of crime and disorder. Zero-tolerance policing meshed well with Giuliani's promise to reclaim the streets of New York for law-abiding citizens. As Judith Greene (1999:173) notes, "cracking down hard on the most visible symbols of urban disorder proved to be a powerful political tool for bolstering Giuliani's image as a highly effective mayor."

Under Bratton's lead, the New York City Police Department (NYPD) initiated a massive restructuring that increased the number of uniformed officers from 27,000 in 1993 to 41,000 in 2001. As Loïc Wacquant (2006:104) notes, this growth in personnel was made possible by an increase in the police budget of 50 percent in five years, topping $\$ 3$ billion in 2000, while, during the same period, social services in the city were cut by 30 percent. Bratton also decentralized authority in the NYPD, moving power out to the individual precincts and boroughs. A computerized information system known as COMPSTAT - meaning "compare statistics" - was introduced to improve the police's knowledge of the occurrence of crime and disorder. A Street Crime Unit was launched in 1994. This elite unit had a militaristic culture; members were known as "commandos" of the NYPD and their motto was "We own the night" (Lynch 2000). By 1996, the unit had grown to 138 officers, and was expanded further to 380 officers after Howard Safir replaced Bratton as Police Commissioner.

During his tenure as Mayor of New York City, Giuliani credited the zero-tolerance policing strategy for realizing a significant reduction in crime and disorder in the city. Despite its detractors (see, for example, Herbert 2001; Grabosky 1999; Greene 1999; Innes 1999; Hopkins-Burke 1998), the zero-tolerance policing strategy has found its way into a number of locales (Newburn 2002; Jones and Newburn 2002; Wacquant 2006) - including the city of Winnipeg.

3. Bratton served as Police Commissioner of New York City from January 1994 to April 1996. 
In November of 2005, the WPS launched "Operation Clean Sweep." "Clean Sweep," as it came to be known, emerged on the heels of an inner-city, gang-related, shooting death of a 17-year-old male bystander one month previously. ${ }^{4}$ With an initial estimated cost of $\$ 1.6$ million, the project involved the deployment of 45 police officers, mainly in the West End, a part of Winnipeg's sprawling inner city. Described as a "take back the streets" and an "in your face" form of policing (Owen 2005), the goal of the project was to suppress street level violence and disorder, "including, but not limited to, gang, drug and prostitution related offences" (Winnipeg Police Service 2006). Like zero-tolerance policing generally, the success of Clean Sweep has been measured by the number of warrants served, arrests, gun and drug seizures, and drug houses shut down. By the end of July 2006, this "clean sweep" approach to policing had netted 873 arrests and 73 apprehensions. In addition, 5,555 spot checks were conducted, 42 search warrants were executed, 897 offence notices were issued and 6,689 police-person hours were logged walking the beat. Some $\$ 990,650$ worth of illegal drugs and firearms were reportedly seized. A "Clean Sweep Tip Line" set up to receive calls from citizens netted 322 calls (Winnipeg Police Service 2006).

In May of 2006, the City of Winnipeg sponsored a by-invitationonly, two-day summit of business and community leaders to examine the economic, social, and infrastructure development opportunities and barriers to creating new initiatives for the city. The keynote speaker was former New York City Mayor Rudolph Giuliani. ${ }^{5}$ Giuliani is reported to have told his audience at the $\$ 260$-a-plate dinner that "Winnipeg can get rid of its image as a high-crime, rundown city by first cleansing the streets of aggressive panhandlers and squeegee kids" (Saunders 2006). He also expressed his enthusiastic support for the use of computerized crime-mapping techniques. Winnipeg Mayor Sam Katz, a sports and entertainment entrepreneur turned civic politician, was quick to act on Giuliani's advice.

Initially designed as a pilot project, Operation Clean Sweep was subsequently bolstered by a $\$ 2$ million contribution from the provincial government and an addition of $\$ 3.5$ million to the police service's overtime budget to make it a permanent feature of policing in the city (Katz 2006).

4. Class and race issues featured prominently in the media coverage of the shooting. Strong emphasis was placed on the fact that the young white man was the son of a surgeon and a recent graduate of an elite private school in the city. The incident was framed in the context of a dispute between members of two rivaling Black gangs in the neighbourhood, the Mad Cowz and the African Mafia.

5. Giuliani was paid $\$ 100,000$ for his services at this event. He was flown to Winnipeg in a private jet at an estimated cost of $\$ 25,000$, paid for by Power Corporation (Lett 2006). 
Adopting the same name as the NYC unit, ${ }^{6}$ Winnipeg's Street Crime Unit comprises 47 officers who work on a citywide basis. In addition, the Winnipeg Police Service launched the first phase of "CrimeStat" in February of 2007. The WPS website displays weekly statistical breakdowns of crimes committed across the city, information that police utilize to identify and respond to crime patterns. According to Mayor Katz, "CrimeStat will measure police effectiveness, hold commanders accountable to delivering results, and use accurate and timely intelligence to assist in the deployment of officers to meet emerging challenges" (Katz 2007a).

These recent moves by the WPS to implement an aggressive, zerotolerance policing strategy suggest - contra Pratt (2007) and Meyer and O'Malley (2005) - that at least one Canadian jurisdiction has not been immune to American-style crime control strategies. That Winnipeg's mayor is enamoured with this approach, delivered in person by a famous former NYC mayor to a congregation of the city's elites, seems clear. ${ }^{7}$ There is also evidence to suggest that this "get tough" approach to the problems of drugs, gangs, and violence in Winnipeg's inner city has popular appeal. Like Giuliani, Mayor Katz won re-election in the fall of 2006 on a platform that showcased his approach to crime control. ${ }^{8}$

But what do the people most directly affected by these policies those who live and work in Winnipeg's inner city - think of the "get tough" approach to crime control? How do they understand the problems of drugs, gangs, and violence? What are their views on aggressive crime control strategies such as Operation Clean Sweep? What role do they envision for the police in their communities? To investigate these questions we interviewed 62 Winnipeg inner-city residents, businesspeople, and community workers with respect to their views on the "crime problem" and the role of the police in their communities.

6. The NYC Street Crime Unit was actually disbanded in 2002 (Court TV News 2002). The unit had come under heavy criticism for its aggressive policing style, especially in relation to concerns about racial profiling of young Black and Hispanic males who were the main targets of "stop and frisk" searches. In February 1999, a young African immigrant was shot and killed by four Street Crime Unit officers in the foyer of his apartment building during one of these routine searches (see Lynch 2000).

7. It is noteworthy that Mayor Sam Katz features a picture of himself with Rudolph Giuliani on the main page of his website; see: www.samkatz.ca (accessed on March 12, 2006).

8. Mayor Katz also writes a regular column in one of the city's two daily newspapers, one of which recently featured the headline, "It's time to get tough on criminals." Calling attention to the problem of "violent crime and gangs," he advocated tougher sentencing as well as highlighting the city's implementation of Operation Clean Sweep, CrimeStat, and the addition of 115 new police officers (Katz 2007b). 


\section{Voices From the InNer City}

Qualitative interviews were conducted in the summer of 2006 in three Winnipeg inner-city neighbourhoods: Centennial, William Whyte, and Spence. Respondents were asked about their perceptions of and experiences with safety and security, their views on the role of the police in responding to crime and violence in their neighbourhoods, and their ideas as to what they thought should be done to make their communities safer. In all, 45 interviews were completed (15 in each of the three communities). ${ }^{9}$ Seventeen community workers who are actively involved in the inner city were also interviewed about their views on the study topic. ${ }^{10}$

Inner-city people are very much aware of safety and security concerns that prevail in their neighbourhoods - especially the problems of drugs, gangs, and violence. One of the interesting findings to emerge from these interviews, however, was the specificity of these concerns in the three inner-city neighbourhoods we studied.

\section{Centennial Neighbourhood}

Residents in Centennial neighbourhood were most likely to express concerns for the safety of young children, a finding likely related to the fact that 12 of the 15 residents we interviewed had responsibility for young children. These caregivers told us that there are certain places and times when they feel their children's safety is at risk. Many said that they would not venture out, and would not allow their children out, at night time, as the dangers seem too great. As one mother commented: "Me and my children don't go out after eight unless it's necessary. If it is necessary, I feel scared. I am scared. I'm always looking over my shoulder." Even during the day there are dangers. Several Centennial residents told of children and youth being harassed or beaten up by other youth, and expressed concerns about their children being exposed to prostitution and drug dealing. One mother told us: "It's disgusting, especially the prostitution, because there are times when I have to walk my daughter

9. To compile a list of prospective study participants, the researchers met with community leaders who are active in and knowledgeable about each neighbourhood. These lists were designed to reflect the diversity of each neighbourhood. Of the 45 respondents who participated, 53 percent (24) self-identified as Aboriginal and 60 percent (27) were female. In terms of age, 14 percent (6) fell into the 20-29 age category, 27 percent (12) in the 30-39 category, 34 percent (15) in the $40-49$, and 25 percent (11) were over 50 years of age.

10. Four interviewers (three of whom are of Aboriginal heritage and all of whom are or have in the past been residents in the communities studied) were hired and trained to conduct the interviews. The interviews were digitally recorded and later transcribed for analysis purposes. 
to school because these johns were approaching her. She misses a lot of school because of it." Another added: "The kids see everything and my girl always says, 'Mom, look, that guy is dealing drugs.' She always says. She knows."

Most of those interviewed in Centennial attributed this violence to the prevalence of the drug trade - and to gangs. One resident remarked: "There's too much drug dealers around here and I don't feel safe at all because there's a lot of shooting and violence." Another said that "crack is getting to be a huge, huge issue.... They've got kids as young as 10 or 11 running around on bikes delivering drugs." A community worker told us, "gangs are a part of what makes it not safe, and they recruit kids and, you know, it's really at the point where kids have to make the decision not to be in a gang, if they don't want to be recruited."

Parents of teens expressed deep fears that their children would be drawn into illegal and/or gang activities. Some have been successful in pulling their children away from such activity. One mother described her long struggle to extract her daughter from such a life: "Well, my daughter Sophia [not her real name], she was in two gangs, she was with Indian Posse and I tried to get her out of it. But I managed. I never gave up on her. Now she's doing really good and she's got two children of her own." Others openly expressed their fears for their teen-aged children in the face of the powerful draw exerted by illegal gang activities:

Well, I know there's gangs, drugs, and violence and I wish it would stop but I don't know how to stop it. I mean, as a parent myself, my boy, I know for one he's involved and I can't stop him.... I could just watch and hope that someday something will wake him up. And most of the kids who are in gangs I've known since they were babies, so it's kinda hard. And how they're getting into them I don't know. I wish there was a way to prevent it because it's pretty deadly.

\section{William Whyte Neighbourhood}

The residents of William Whyte also expressed concerns about safety and security. A noticeable difference, however, is that the presence of violence in this community seems to have become "normalized"; violence has come to be understood as a regular feature of everyday life in the North End of Winnipeg. As one woman told us, "We live next door to a crack house and next door to a gang house, so I don't know how safe I'm supposed to feel?... I guess we have the respect. They don't bother us and we don't bother them kind of thing." When asked whether there were particular times or places where she didn't feel safe, another woman replied: "Not really because I grew up in the North End so it 
doesn't bother me." As one community worker who works with streetinvolved women put it:

You know, what amazes me a lot, what I hear from the women, is how they accept that violence is a part of their day-to-day life, like, a story that would horrify me if it happened to me or anybody that I know outside of work, but that's something that's part of their everyday life, and that's the horrifying part. It's how normal it's become for them, to take risks like that and to be injured and to be [physically] assaulted and to be sexually assaulted.

While violence has been normalized as "something that's part of everyday life," that is not to say that William Whyte residents do not take precautions or alter their behaviour as a result. Many spoke of the strategies they use, such as avoiding being around particular places (a local drinking establishment, for instance) and never walking the streets at night, especially by themselves.

William Whyte residents described the "gang" in a way that countered the negative stereotypes typically associated with the concept. For these residents, gangs were simply the young men who live in the neighbourhood; young men who are their sons, nephews, uncles, and brothers. As one resident told us: "I don't see them as stereotypical gangs.... I just see them as my neighbours, if anything, just because they are. Just because I think I have a better understanding of who they are, why they're there." Another remarked, "There's no gangs, it's just people that know each other.... It's not a big gang problem.... Big gang of kids selling dope, that's all it is." But while gangs were reframed in this way, the activities associated with them were condemned. One of the residents remarked: "It's not the gangs that are really the problem; it's just the dealers and the people that are buying." Another commented: "We don't have a lot of gang activity that we can see.... Prostitution is a big thing because they work right on the end of the street there."

There was a strong sense in the William Whyte community that the drug trade - especially crack cocaine and crystal meth - was becoming a more serious problem. A community worker who has lived most of her life in the neighbourhood told us:

I think it's a different era, and really, the drugs, I haven't seen a drug so devastating as this crystal meth. It seems to be so addictive that people lose all their genuine self, themselves, their being and their love for other people. They lose all that and they just have a love for this drug and it's, so, and you do crazy things when you're controlled by a drug, you know, you're not controlled by emotions anymore. So I'd say that, I think that is the biggest thing. 
The presence of the drug and sex trades has generated concerns about the safety of the children in the neighbourhood. Residents spoke of their worries about needles littering the neighbourhood, and young children being exposed to and involved in drugs and prostitution. As one resident said, "I seen a 15-year-old doing crack and he looks like he's maybe 40, 50 years old already, and he's only 15." When asked whether there were rivalries with gangs he responded: "Not really, I don't see none of that. Just mostly crack dealers trying to get the younger ones in." Another resident expressed a similar concern:

Small kids, they come out and see this bullshit every day. There's hookers, and some of them are 11, 12 years old. So it's crazy. Sometimes they're out there five, six o'clock in the morning ... these young girls, like, where they should be sleeping, going to school. And no, they're out there hooking.

Yet, while William Whyte residents were well aware of the safety and security problems that existed, and while violence has become a normalized feature of their everyday lives, they also took considerable pride in their community. For them, the North End is home:

I'd rather walk around in the North End than anywhere else. I feel safer here. I know more people.

I've lived here for thirteen years. To me, it's okay. Nobody bothers me.

There's a safety net here, there is ... for Aboriginal people there is. There's a safety net, a comfort level.

\section{Spence Neighbourhood}

According to most of the residents interviewed in the Spence neighbourhood, problems of safety and security are less serious now than in previous years. As four of the respondents commented:

The violence I think is really not as prevalent as it used to be.

Oh I think it's much safer than it was five years ago.... I've talked to my neighbours, I've talked with my fellow people that I work with all over the place, and everybody has noticed that it's much different now.

I've never had any sort of threat to my personal safety whatsoever, and I do a lot of walking around the community.

I do actually, yeah, I don't know if it's a delusion [laughs] but I do feel safe, yeah. 
Yet there are still safety and security problems in Spence. Many identified groups of young people walking around late at night as the source of problems and the cause of fear. One man described them as "these big packs of youth that worry me the most," while another expressed concern about "seeing gangs walking around, packs of kids, you know they're looking for trouble. They're not just out for a walk, kind of thing, they're looking for trouble."

While many mentioned young people being out and about late at night as a cause for fear, it is not clear whether these are gang members or merely groups of young people with nothing to do. One person, for example, told us:

These kids hanging outside 7-Eleven with their hats tilted doesn't necessarily mean a gang, but the way people perceive is often through the media, and this is what they are told is the gang sign or whatever, and so there's a problem. You know, many of these kids, if you get past the tough exterior they're actually pretty good kids.

Yet it cannot be denied that there is gang activity, it is dangerous, and vulnerable youth are at risk of being drawn in. Aboriginal youth are particularly at risk, as are new immigrant and refugee youth. One resident told us that with new immigrant and refugee youth:

The parents don't have a familiarity with our society or with our culture.... And a lot of these kids then build their own social group apart from the safety of their parents or their cultural group and that's when they get pulled into gangs or into dangerous situations.... And often their parents have to work extraordinarily long hours if they're going to support the family. And I see that with a lot of the families, like, the mothers working all night, the fathers working all day. Sometimes in the evening they're both working and there's nobody at home. So the kids, as I say, they build their own social networks which aren't always that safe.

Similar to Centennial and William Whyte, drugs such as crack and crystal meth have become a pressing problem in Spence. We were told that:

If you go back ... even 10 years ago or seven or eight years ago, you didn't hear as much talk about crystal meth and crack, and they're very highly addictive and they damage the chemical in your brain. You become a different person. So we're seeing more children out on the street working in the sex trade, we're seeing more crimes that aren't planned. You know, they just kick somebody's door in. They just want to get money and get a fix right away. 
Businesspeople reported that crime and the perceptions of crime in the Spence neighbourhood adversely affected their businesses. One described customers being propositioned by street sex workers as they entered or left his shop, and one case of a customer almost having a purchase stolen from her by a group of young men as she walked to her car. Other business owners remarked on the serious downturn in their businesses after the shooting in late 2005 that resulted in the death of a young man. One said that he "easily lost $\$ 30,000$ " and that "it's taken me years to build up that kind of business." Another told us: "It curtailed business because people saw it on the news.... The [business] was filmed, there were bullets lodged in the wall." Spence "has already got the connotation of being a crime-ridden neighbourhood, so people read that and it just feeds more into that perception they have of the neighbourhood."

Despite the specificity of the concerns expressed by residents, businesspeople, and community workers in each of these inner-city neighbourhoods, safety and security issues appear to be prominent in all three communities. This is consistent with the Canadian Centre for Justice Statistics finding, referred to earlier, that the closer one goes to the geographic centre of Winnipeg, the higher is the incidence of crime (Fitzgerald et al., 2004). Making matters worse, however, was the lack of confidence in - and, in some cases, fear and distrust of - the police expressed by many of those we interviewed.

\section{InNer-City Views on Policing}

With the heightened concerns about drugs, gangs, and violence in the inner city, the role of the police in these neighbourhoods becomes all the more significant. The primary strategy adopted by the WPS in the inner city has been the traditional model of reactive, incident-driven policing, whereby general patrol officers spend their shifts in cruiser cars, responding to 911 calls. There is community policing in parts of the inner city, such as the School Resource Program and some foot patrol officers, but its strength is often depleted when community officers are called away to perform other duties. With the introduction of Operation Clean Sweep in November of 2005 and the implementation of the more permanent Street Crime Unit the following year, there has been a decided shift toward a more aggressive, zero-tolerance policing strategy by the WPS. Our interviews provided an opportunity to tap into the views of people in the inner city about the role of police in their community. As one of the neighbourhoods surveyed (Spence) was the target of Operation Clean Sweep, we were able to glean their standpoints on this project. 
Residents in Centennial told us that they rarely see the police in their neighbourhood. As four of the respondents commented:

I never see the police.

I've had problems where I've called the police many occasions and nothing's been done.

I never see them around.... I don't see any kind of patrolling around here.

I haven't seen any police at all, foot patrol, whatever. I haven't seen anybody.

At the same time, the residents told us of their dislike, and even fear, of the police. Several residents based their assessment on what they considered to be racism on the part of police officers:

I think it's all reactive, almost all, just reacting to crisis, and even then they're not, there aren't enough of them to do that well. And I think there is a lot of racism and that, you know, kids get targeted.... I couldn't say they're doing a good job.

Many people are afraid to call the police ... and some of the immigrant groups have had, in their countries have had terrible experiences with police, so they're scared to make phone calls.

I don't really get along with them [the police] and I don't think they're really helpful in some ways because most of them are racist.

Despite the negative opinions of the police voiced by many Centennial residents, almost all of those we interviewed saw the need for - and wanted - an active role for the police in their neighbourhood. In particular, respondents told us that they want to see the police regularly, walking the beat. They want the "cop on the beat" to get to know the neighbourhood and its people - especially the children. One of the community workers we spoke to indicated that a community police officer had been assigned to work in Centennial for three years, and that "he did some really good work with us." However, the officer "was here about a quarter of the time in the end. He was being called out to do other things all the time," outside of the neighbourhood. According to this worker, "I don't think one person can do it here, and especially not if they're calling them away all the time."

While some William Whyte respondents believe that the police "try to do the best they can" and are "doing as much as they can do, as much 
as they're allowed to do," numerous people told us that the police are slow to respond to troubles in the neighbourhood. As one resident put it,

Well, actually, when you do need them they're not around. Like, all that stuff that happens around here, like when it's happening, you don't see a police officer anywhere, and then, sure, after everything quiets down that's when they show up.

Several of the William Whyte residents expressed concerns about racial profiling by police officers. One woman described a visit by the police to her home after she called them about an incident:

Like, I make sure I always have a lot of nice stuff in my house and that, like, I buy the stuff myself, and one time a police officer came in here and said, 'oh, you have so much nice stuff, you must be doing good in the business.' And I says, 'what are you talking about?' He says, 'oh, only crack dealers own this kind of stuff.' I said, 'well, I'm not a damned crack dealer. I buy this stuff out of my own pocket.' And I found that he, oh, he just really kind of pissed me off, like, just because I'm Native I'm not allowed to have nice stuff?

Another woman expressed anger about police engaging in what she called "spatial profiling," saying, "so just because you live in a certain neighbourhood then you're a criminal, you're a this or a that, all these negative stereotypes." This spatial profiling includes stereotyping young people in the neighbourhood. One resident said:

I think they [the police] profile any Native kid that's walking down the street. I make sure, I watch and I make sure that they're not out to hurt anybody.... Personally, I've witnessed police brutality.

An Aboriginal mother told us that her son, who likes to jog, "can't run down the street" because he is subject to being stopped by police. A community worker commented:

I don't know when it became a crime to be a teenager, but apparently it is because a lot of teenagers get harassed by police, and if they're walking down the street in a group of more than two - which is frequently the case because teenagers like to hang out in groups - then they're called a gang and they're treated like a gang. I also know of teenagers who have been pulled over by the police and harassed and threatened and beaten by police and who were told they were dealers of drugs when they were not. Now, how's that going to teach a young person respect for the law? I don't think it does, and I know this to be a fact because I've seen it happen. 
A young Aboriginal woman expressed the view - yet another expression of spatial profiling - that things are different in more well-todo areas of the city:

Like, in the rich area, like, they get a lot of attention and a lot of the people there feel a lot better that there's a presence. And not only that, but the kids see them and it's kind of like a friendly atmosphere, you know.

But in the North End, she added, the police "can't get out of their vehicles to walk on the street, [and they] point fingers and look down at us." To the extent that the police operate on the basis of these kinds of stereotypes and assumptions, the result, almost inevitably, will be conflict.

It is clear from our interviews that many people in William Whyte fear and distrust the police. As one resident commented,

They've got power issues.... I think the police have a very negative role in my community. A lot of the community, they don't respect the police, they don't call the police, you know. The community kind of takes it upon themselves to deal with stuff as opposed to calling the police.

Referring to young people in the neighbourhood, a woman in her 50s who has lived there most of her life said:

A lot of them are scared of the police because the only time they see the police is either they're picking up their big brother or their father or something, so they see them as negative.

This woman added:

... people shouldn't be afraid to talk to you [the police], but they're afraid to talk to you because I might look like someone that you're looking for and you're going to beat me up before you find out I'm not that person.

She was quick to say that "it's not all policemen," yet there are enough stories about the rough treatment by the police of people in the neighbourhood, and particularly of young Aboriginal men, that the result is fear and distrust of the police in general. A young Aboriginal woman described it this way: "I think there's a lot of prejudice that goes both ways, the police to the people and from the people to the police. And they don't trust each other, they don't get along. They knock heads."

In Spence neighbourhood, some of the people we spoke with feel positively about the police. A building superintendent, for example, commented:

We've had the police here I would say 20,30 times, and they're absolutely magical in their ability to calm people. Most of our disturbances were 
alcohol by nature so the people were very unruly, very violent, and very difficult to talk to. And the police come in and they just calm the situation so well. I'm just so impressed with the police.... In all, the police do an exceptional job of calming people.

Most people we spoke to in Spence, however, were much less positive. There was, we were told by many, a limited police presence in Spence. One person said:

Well, there's not police presence, you don't see cops walking the beat or anything like that. You see them drive by in their cruisers, and you're lucky if you can get them out of that cruiser, kind of thing. You know, that's where they are and that's where they stay.

As in Centennial and William Whyte, residents in Spence raised concerns about racial profiling by police officers. One Aboriginal woman told us:

I've talked with other women who've had their sons and brothers who have been roughed up by the police for no reason at all, other than the police want to. I don't know, I think, have some fun and assert their authority.

A long-time community worker in Spence said much the same:

One of the things that's raised its ugly head in the last few years around here is that there are some really bad apples in the police department who are racist, who are violent towards community people, who harass people for no good reason. So, I mean, that's a serious concern. I don't believe by any stretch that it's all or even most of the police department that behave in that way, but I think that there are significant numbers that do. There are just too many stories that we hear to ignore it.

Spence neighbourhood was the focus of Operation Clean Sweep, initiated some nine months prior to our interviews with the residents. When asked, several people said they like Clean Sweep because it signalled a concerted effort on the part of the police to address neighbourhood problems. Some liked Clean Sweep because they consider it important that there is a visible police presence in the neighbourhood, and with this project the police became more visible.

The whole idea of Operation Clean Sweep thing has positive effects in that there's more of a police presence and they're more focused with dealing with, not just responding to, this thing or that thing but actually following what's happening within the gang activity and within the drug activity in the community. 
I think there's a lot of people in the community who are happy about it [Clean Sweep]. They're kind of happy to see any kind of measure that's going to try and deal with some of the violent stuff that occurs.

I would say, for the most part, from talking to community members daily, that for the most part, people feel safer. So I think that's good.

On the other hand, many of those we interviewed were critical of Clean Sweep. For instance, one person said that Clean Sweep moved gangs out of Spence, but that they moved right back in when there was a pause, and will be moved out again when Clean Sweep resumes:

During the process of having Operation Clean Sweep happening here it [the gang presence] was very minimal, where it was visible. Being that it's the end of the month and the police are dealing with their own staffing problems right now, they [the gangs] are more prevalent again and that's, I can see, coming to an end towards May when the police is back to its full force again, and they continue on with their new version of Operation Clean Sweep [the Street Crime Unit].

Another said much the same: "I mean, sure they [the police] have presence, but at some point the presence is going to wane and then what?" A third told us that "I see Operation Clean Sweep as somewhat of an emergency measure that should be longer than three months, but maybe not forever, and maybe after a year or a year and a half resources could be funnelled into the community policing piece."

The views of people in Spence about Operation Clean Sweep were nuanced. Few were totally favourable or totally unfavourable. Many were saying that Clean Sweep is good because the increased police presence reduces crime, and they have been concerned about the lack of a police presence in their community. But they were also saying that Clean Sweep is not a long-term solution to the problems in the community.

\section{Neighbourhood ReVitalization}

One of the insights to emerge from these interviews with inner-city people is the sophisticated understanding they hold of the pressing problems of gangs, drugs, and violence in their communities. One resident assessed the prevalence of gangs as follows: "I really think it's related to poverty. I think kids get recruited in it because they don't see any other options so it's a way of having money, a way of having some power." Another marked out the connections between drugs and crime, saying that the big issue 
for the last couple of years has been [that] the crack and meth situation in the community has really made people that normally wouldn't be violent or vicious, you know, their lives are changing and they're changing in order to get their next fix so they're doing crazy things.

A third inner-city resident was of the view that the problems were not simply internal to the inner city, but connected to the actions of those outside the community:

A lot of people in the community have expressed that it's not so much just the gangs and prostitution that they're scared of, it's outsiders that come in for those services ... johns coming around ... the more upper class people are coming in, the ones with the money.

Following from this understanding of inner-city problems as complex and deeply rooted, a particularly strong viewpoint held by residents in all three of the communities was that long-term solutions were to be found, not in "get tough" policing strategies, but in neighbourhood revitalization. As one resident remarked, "I think it's not so much the police, it's the community itself. It has to be the community first to do the work, and the police as backup." A second added that, "the community really needs to take back their community, the neighbourhood." A third respondent said much the same: "We tend to look, I guess, that the outside can come in and clean this up. But it's really the inside out. We have to clean ourselves up."

This notion is consistent with the fact that Winnipeg's inner-city communities have, especially in the past decade or so, witnessed the considerable development of community-based organizations engaged in neighbourhood revitalization efforts (Deane 2006; Silver 2006b; CCPA-MB 2005; 2006; 2007). Housing is being renovated, community gardens are being created, youth programs are being established, and, in a number of neighbourhoods, a turnaround appears to be underway. For instance, several of the residents in Spence, where Operation Clean Sweep was concentrated, were of the view that the reason their neighbourhood was much safer now was due to the efforts of their local neighbourhood association. A local businessman told us:

You look down, say, Langside Street, ${ }^{11}$ I remember two, three years ago and boarded up houses like crazy, you know, and that was scary. Now I think you probably don't see one boarded up house anymore ... and some of these places have been fixed up and there are families living in there now who seem to care for the property and for the neighbourhood -

11. Ten years earlier, Langside Street was commonly referred to as "Gangside Street" (Silver, 2006c). 
which is very good. And what we need is more of that, so as the place gets cleaned up then the neighbours around do the same. And it does change the image of the area. But like I said, that is a positive step since three, four, five years ago or so, you know.

It is within this context that many inner-city people envision a role for the police. Rather than being an outside force that comes into the neighbourhood in response to incidents, they want the police to become part of this community revitalization process, to work in partnership with the community residents and community organizations and businesses. This community-based model would involve the police walking the beat, getting to know the neighbourhood - particularly the children and youth - and ultimately earning the trust of the people. As a consequence, police would be able to develop a highly sophisticated intelligence system about who is doing what in the neighbourhood, and to work with the community in a proactive fashion to prevent problems before they arise. One long-time community worker in Spence, when expressing her concerns about Operation Clean Sweep, put it this way:

It isn't balanced with a community-based approach. Like, if you had a real strong, intensive, committed community-based policing program, I'm not sure that you would need that kind of a big hammer kind of approach. I'm not saying you don't need, you know, you need the cops to deal with the guys who are breaking the law and stuff, that's their job for sure, but I think it needs to be balanced, also, with a community-based approach.

An interesting paradox emerged in the interviews with inner-city people: many said that they distrust and dislike the police but at the same time they want a greater police presence in their neighbourhoods. On closer examination, what we found is that respondents were objecting to an aggressive, incident-driven form of policing that pits the police against the community. People want a police presence but they want the police to work in partnership with the community, building relationships and creating trust. To this extent, the move to a zero-tolerance policing strategy appears to be going in the opposite direction from the kind of policing that many inner-city residents - those most directly affected by crime and violence - say they want for their communities.

\section{A Punitive Turn?}

At first glance, the argument that Winnipeg is a Canadian exception to the punitive turn seems to be confirmed when we examine recent events in the city, specifically, the move to implement a zero-tolerance policing 
strategy to respond to problems of drugs, gangs, and violence. On further investigation, however, we find that many of those who live and work in Winnipeg's inner city, while concerned about safety and security issues, have a much more nuanced view of crime control strategies than can be captured by use of the term "penal populism." Most appear not to be supporters of the punitive turn. Indeed, many articulate very clearly the outlines of an alternative inner-city policing strategy that offers a more progressive approach to inner-city crime control.

The standpoints of inner-city residents provide us with a reading that counters the one-dimensional, stereotyped view of the inner city as a "dangerous space." While all too accustomed to dealing with the daily presence of gangs, drugs, and violence, inner-city people have a strong sense of pride in their community and an optimism that things can get better. As one resident told us,

I think this community is a very vibrant community. I think a lot of good things are happening in this community, you know, and I think that one of the biggest keys to change things is to really focus on this community as a community that has a lot of strength.

Many of the inner-city people we interviewed expressed fears about their own children being drawn into gang and related illegal activity, while at the same time expressing a deep understanding of why this happens to the youth in their community and a compassion for youth growing up in the midst of the harsh realities and limited opportunities that characterize inner-city life. While none condoned gang activity, many maintained that often the young people identified are not in fact gang members but disaffected youth with not enough to do. And about those who are gang members, the view frequently expressed was that in the absence of meaningful job prospects, the seemingly omnipresent trade in illegal drugs becomes an attractive and potentially lucrative alternative, leading inexorably to a host of serious safety and security concerns. It is within this context that inner-city residents envision a different role for police - not as an aggressive, external force that reacts to crime but as one part of a wider effort of community mobilization in which the police work with the community to implement community-driven solutions for the problems that engender crime and violence.

Some criminologists question the claims of penal populism and the punitive turn in Western societies. Neil Hutton's (2005) research in Scotland on public attitudes towards sentencing, for instance, determined that evidence for the existence of a punitive mood on the part of the Scottish public is less certain: Hutton found public opinion on punishment to be contradictory, nuanced, and fragile. In a similar vein, Roger Mat- 
thews (2005:195) makes the important point that "most of the examples of punitiveness that have been presented in the literature represent more extreme and exceptional developments and ... most are limited spatially or temporally." He notes (2005:194), for instance, that the introduction of zero-tolerance policing in the United Kingdom was short-lived and that, as in the United States, the extent of its adoption and implementation was never clear.

The support for zero-tolerance policing strategies to resolve Winnipeg's inner-city problems may be consistent with what Jock Young (1999:130) has referred to as the "general cultural disposition to believe in the easy miracle and the instant cure." In this regard, the move to zero-tolerance policing may be more about symbolic politics - about the need to be seen to be "getting tough" on crime - than about actual policing strategies. As Tim Newburn (2002:176) has observed, "toughness" has become the "most potent form of symbolism in penal-political discourse in recent times," while its opposite - being "soft on crime" - has become "the crowning curse of political discourse."

Yet, in the case of Winnipeg, many of those most directly affected by crime and by policing strategies in response to crime - that is, those who live and work in Winnipeg's inner city - appear not to be affected by this "crowning curse of political discourse," nor by "the cultural disposition to believe in the easy miracle and the instant cure." Although deeply concerned about the problems of drugs, gangs, and violence, many eschew the easy solutions purportedly to be found in the punitive turn. There are no easy or instant miracle cures for the deep and complex, racialized, and crime-inducing poverty in Winnipeg's inner city. That people in Winnipeg's inner city are resisting "get tough" strategies of crime control, and instead are advocating for a police role in community mobilization, suggests the potential for a more meaningful, longterm response to the problems in their neighbourhoods. Whether or not this strategy will take hold is open to question, but the tenacity of many inner-city people and their resolute belief that such change is necessary and possible are grounds for optimism.

\section{REFERENCES}

Brodeur, Jean-Paul, ed. 1998. How to Recognize Good Policing: Problems and Issues. Thousand Oaks, CA: Sage Publications.

Brown, Jason, Nancy Higgitt, Christine Miller, Susan Wingert, Mary Williams, and Larry Morrissette. 2006. Challenges faced by women working in the inner city sex trade. Canadian Journal of Urban Research 15(1):36-53. 
Canadian Centre for Policy Alternatives-Manitoba (CCPA-MB). 2005. The Promise of Investment in Community-Led Renewal: State of the Inner City Report, 2005. Winnipeg: Canadian Centre for Policy AlternativesManitoba.

2006. Inner-City Voices, Community-Based Solutions: State of the Inner City Report, 2006. Winnipeg: Canadian Centre for Policy AlternativesManitoba.

2007. Step-by-Step: Stories of Change in Winnipeg's Inner City: State of the Inner City Report, 2007. Winnipeg: Canadian Centre for Policy Alternatives-Manitoba.

Clairmont, Donald. 1991. Community-based policing: Implementation and impact. Canadian Journal of Criminology (July-October):469-84.

Court TV News. 2002. NYDP street crime unit dismantled. www.courttv.com/ archive/news/2002/0410/NYCcrimeunit ap.html (accessed on February 2, 2007).

Deane, Lawrence. 2006. Under One Roof: Community Economic Development and Housing in the Inner City. Halifax: Fernwood Publishing.

Deane, Lawrence, Dennis Bracken, and Larry Morrissette. 2007. Desistance within an urban Aboriginal gang. The Journal of Community and Criminal Justice 54(2):125-41.

Dumaine, François and Rick Linden. 2005. Future directions in community policing: Evaluation of the Ottawa police service community police centres. The Canadian Review of Policing Research vol 1. Available at: http:// crpr.icaap.org/index.php/crpr/article/view/43/49 (accessed October 6, 2006).

Fitzgerald, Robin, Michael Wisener, and Josée Savoie. 2004. Neighbourhood Characteristics and Distribution of Crime in Winnipeg. Ottawa: Canadian Centre for Justice Statistics. Catalogue no. 85-561-MIE.

Fontaine, Nahanni. 2006. Surviving colonization: Annishinaabe Ikwe gang participation. In G. Balfour and E. Comack, eds., Criminalizing Women: Gender and (In)justice in Neo-liberal Times. Halifax: Fernwood Publishing.

Garland, David. 2001. The Culture of Control: Crime and Social Order in Contemporary Society. Chicago: University of Chicago Press.

Grabosky, P.N. 1999. Zero tolerance policing. Trends and Issues in Crime and Criminal Justice. Canberra: Australian Institute of Criminology (January).

Greene, Jack. 2000. Community policing in America: Changing the nature, structure, and function of the police. Criminal Justice 3:299-370.

Greene, Judith A. 1999. Zero tolerance: A case study of police policies and practices in New York City. Crime and Delinquency 45(2):171-87. 
Hamilton, Alvin and Murray Sinclair. 1991. The Justice System and Aboriginal People: Report of the Aboriginal Justice Inquiry. Vol. 1. Winnipeg: Queen's Printer.

Herbert, Steve. 2001. Policing the contemporary city: Fixing broken windows or shoring up neo-liberalism? Theoretical Criminology 5(4):445-66.

Hopkins-Burke, Roger. 1998. The socio-political context of zero tolerance policing strategies. Policing: An International Journal of Police Strategies and Management 21(4):666-82.

Hutton, Neil. 2005. Beyond punitiveness? Punishment and Society 7(3):24358.

Innes, Martin. 1999. 'An iron fist in an iron glove?' The zero tolerance policing debate. The Howard Journal 38(4):397-410.

Jones, Trevor and Tim Newburn. 2002. Learning from Uncle Sam? Exploring U.S. influences on British crime control policy. Governance: An International Journal of Policy, Administration, and Institutions 15(1):97119.

Katz, Sam. 2006. We can slash the crime rate. Winnipeg Sun May 28.

2007a. CrimeStat website launched. Available at: http://www.samkatz. ca/; accessed March 26, 2007).

2007b. It's time to get tough on criminals. Winnipeg Sun 29 July. Available at: http://www.winnipegsun.com/News/Columnists/Katz Sam/2007/07/29/pf-4376949.html; accessed on December 13, 2007.

Kazemipur, Abdi and S.S. Halli. 2000. The New Poverty in Canada: Ethnic Groups and Ghetto Neighbourhoods. Toronto: Thompson.

Kelling, George. 1974. The Kansas City Preventive Patrol Experiment. Washington, DC: Police Foundation.

Knockwood, Isabelle. 2001. Out of the Depths: The Experiences of Mi'kmaw Children at the Indian Residential School at Shubenacadie, Nova Scotia (3rd edition). Halifax: Rosewood.

Leighton, Barry. 1994. Community policing in Canada: An overview of experience and evaluations. In D. Rosenbaum, ed., The Challenge of Community Policing: Testing the Promises. Thousand Oaks, CA: Sage Publications.

Lett, Dan. 2006. Mayor's critics plan alternative summit. Winnipeg Free Press August 21.

Lezubski, Darryl, Jim Silver, and Errol Black. 2000. High and rising: The growth of poverty in Winnipeg. In J. Silver, ed., Solutions that Work: Fighting Poverty in Winnipeg. Halifax: Fernwood Publishing.

Linden, Rick, Donald Clairmont, and Christopher Murphy. 2000. Aboriginal Policing in Manitoba: A Report to the Aboriginal Justice Implementation Commission. Winnipeg: Manitoba Justice. Available at: http://www.ajic. $\underline{\mathrm{mb} . c a / c o n s u l t . h t m l}$ (accessed on August 22, 2006). 
Lynch, Timothy. 2000. 'We own the night' Amadou Diallo's deadly encounter with New York City's street crimes unit. CATO Institute Briefing Papers No. 56 (March 31). Washington, DC: CATO Institute.

Matthews, Roger. 2005. The myth of punitiveness. Theoretical Criminology 9(2):175-201.

McLeod, H. 2004. A glimpse at Aboriginal-based street gangs. A Report for the Royal Canadian Mounted Police "D” Division, Winnipeg, Manitoba for the National Aboriginal Policing Forum held in Ottawa, Ontario. Hosted by Pacific Business and Law Institute, September 22 and 23.

Meyer, Jeffrey and Pat O'Malley. 2005. Missing the punitive turn? Canadian criminal justice, 'balance", and penal modernism. In J. Pratt, D. Brown, M. Brown, S. Hallsworth, and W. Morrison, eds., The New Punitiveness: Trends, Theories, Perspectives. Cullompton, UK: Willan Publishing.

Milloy, John. 1999. A National Crime: The Canadian Government and the Residential School System, 1879 to 1986. Winnipeg: University of Manitoba Press.

Morash, Merry and J. Kevin Ford, eds. 2002. The Move to Community Policing: Making Change Happen. Thousand Oaks, CA: Sage Publications.

Murphy, Christopher. 1993. The development, impact and implications of community policing in Canada. In J. Chacko and S. Nancoo, eds., Community Policing in Canada. Toronto: Canadian Scholar's Press.

Newburn, Tim. 2002. Atlantic crossings: 'Policy transfer' and crime control in the USA and Britain. Punishment and Society 4(2):165-94.

Pratt, John. 2000. The return of the wheelbarrow men: Or, the arrival of postmodern penality? British Journal of Criminology 40(1):127-45. 2007. Penal Populism. London: Routledge.

Pratt, John, David Brown, Mark Brown, Simon Hallsworth, and Wayne Morrison, eds. 2005. The New Punitiveness: Trends, Theories, Perspectives. Cullompton, UK: Willan Publishing.

O'Malley, Pat. 1999. Volatile and contradictory punishment. Theoretical Criminology 3(2):175-96.

Owen, Bruce. 2005. 'In-your-face' blitz unveiled. Winnipeg Free Press October 26.

Ritzer, George. 2004. The McDonaldization of Society. Thousand Oaks, CA: Pine Forge.

Sanders, Jim. 2006. Sightless eyes: Recent events show the city's leaders lack the vision to fix it. Uptown Magazine. May 18.

Seshia, Maya. 2005. The Unheard Speak Out. Winnipeg: Canadian Centre for Policy Alternatives-Manitoba. 
Sherman, Lawrence. 1974. The sociology of the social reform of the American police: 1950-73. Journal of Police Science and Administration 2:25562 .

Silver, Jim. 2006a. North End Winnipeg's Lord Selkirk Park Housing Development: History, Comparative Context, Prospects. Winnipeg: Canadian Centre for Policy Alternatives-Manitoba. 2006b. In Their Own Voices: Building Urban Aboriginal Communities. Halifax: Fernwood Publishing.

2006c. Gentrification in West Broadway? Contested Space in a Winnipeg Inner-city Neighbourhood. Winnipeg: Canadian Centre for Policy Alternatives - Manitoba.

Simon, Jonathan. 1997. Governing through crime. Pp. 171-90 in L.M. Friedman and G. Fisher, eds., The Crime Conundrum: Essays on Criminal Justice. Boulder, Colorado: Westview Press.

1999. They died with their boots on: The boot camp and the limits of modern penality. Social Justice 22:25-48.

Statistics Canada. 2005. Crime statistics. The Daily. Thursday, July 21. Available at: http://www.statcan.ca/Daily/English/050721a.htm (Accessed on August 8, 2006).

Sudbury, Julia, ed. 2005. Global Lockdown: Race, Gender, and the Prison-industrial Complex. London: Routledge.

Wacquant, Loïc. 2000. The new 'peculiar institution': On the prison as a surrogate ghetto. Theoretical Criminology 4(3):377-89.

2001. The penalisation of poverty and the rise of neo-liberalism. European Journal on Criminal Policy and Research 9:401-12.

2006. The 'scholarly myths' of the new law and order doxa. Socialist Register: 93-115.

Wilson, James Q. 1975. Thinking About Crime. New York: Basic Books.

Winnipeg Police Service (WPS). 2006. Operation Clean Sweep. Available at: www.winnipeg.ca/police/ (accessed on August 23, 2006).

Young, Jock. 1999. The Exclusive Society. London: Sage Publications.

Elizabeth Comack is Professor and Head of the Sociology Department at the University of Manitoba. She has published in the areas of social inequality and the law, the criminalization of women, and gender and violence, including most recently Out There/In Here: Masculinity, Violence, and Prisoning (Fernwood Publishing, 2008).

Jim Silver is Professor and Chair of the Politics Department and Co-Director of the Urban and Inner-City Studies program at the University of Winnipeg. He has published extensively on community development in Winnipeg's inner city, including most recently, The Inner Cities of Saskatoon and Winnipeg: A New and Distinctive Form of Development (CCPA-MB, 2008) and In Their OwnVoices: Building Urban Aboriginal Communities (with Parvin Ghorayshi, Joan Hay, and Darlene Klyne, Fernwood Publishing, 2006). 